\title{
Hubungan Tingkat Kecemasan terhadap Kualitas Tidur pada Mahasiswa Angkatan 2018 Fakultas Kedokteran Universitas Kristen Krida Wacana
}

\author{
Alda Vania Sugiarta ${ }^{1}$, Citra Rencana Perangin-Angin ${ }^{2}$, Suparto $^{2}$, Irvan ${ }^{2}$ \\ ${ }^{1}$ Fakultas Kedokteran dan Ilmu Kesehatan Universitas Kristen Krida Wacana \\ ${ }^{2}$ Departemen Anestesi Fakultas Kedokteran dan Ilmu Kesehatan Universitas Kristen Krida \\ Wacana \\ Alamat Korespondensi:.irvan2@gmail.com
}

\begin{abstract}
Abstrak
Kecemasan dapat berdampak pada beberapa hal, salah satunya terganggunya kualitas tidur. Penelitian ini menguji korelasi antara tingkat kecemasan dengan kualitas tidur pada mahasiswa kedokteran tingkat pertama (angkatan 2018). Studi analitik potong lintang dengan teknik pengambilan sampel acak sederhana di Fakultas Kedokteran Universitas Kristen Krida Wacana dilakukan dengan menilai tingkat kecemasan menggunakan kuesioner Zung Self Rating Anxiety Scale, dan kualitas tidur menggunakan kuesioner Pittsburgh Sleep Quality Index. Dari 106 responden, didapatkan hasil 83 responden mengalami kecemasan ringan, di antaranya 30 responden mengalami kualitas tidur baik dan 53 responden mengalami kualitas tidur buruk, sedangkan 21 responden mengalami kecemasan sedang yang terdiri atas satu responden yang mengalami kualitas tidur baik dan 20 responden yang mengalami kualitas tidur buruk, serta dua responden mengalami kecemasan berat yang terdiri atas satu responden dengan kualitas tidur baik dan satu responden dengan kualitas tidur buruk. Data diproses melalui SPSS 16.0 yang selanjutnya analisis menggunakan uji chi square dengan derajat pemaknaan $10 \%$. Penelitian ini menemukan hubungan antara tingkat kecemasan dengan kualitas tidur $(\mathrm{p}=0,016)$. Mayoritas mahasiswa kedokteran tingkat satu mengalami kecemasan ringan. Perlu dilakukan penelitian jangka panjang untuk melihat perubahan tingkat kecemasan dan kualitas tidur sejalan dengan proses pendidikan.
\end{abstract}

Kata kunci : kecemasan, kualitas tidur, mahasiswa kedokteran

\section{Associaton between Anxiety and Sleep Quality among Students from the Faculty of Medicine Krida Wacana Christian University Year 2018}

\begin{abstract}
Anxiety can cause various problems, including poor quality of sleep. This research tests the correlation between the anxiety level and sleeping quality among first year medical students (year 2018). This cross-sectional analytical study using simple random sampling at the medical school of Krida Wacana Christian University rates the level of anxiety was conducted using Zung Self Rating Anxiety Scale Questionnaire andPittsburgh Sleep Quality Index. From 106 respondents, 83 of them experienced low anxiety, 30 of whom had good quality sleep and 53 had bad quality sleep. On the other hand, out of 21 respondents with moderate anxiety, only one experienced good quality sleep and the remaining 20 did not. Two respondents reported high levels of anxiety, one of whom reported good quality of sleep while the other did not. The data was processed using SPSS 16.0 chi square test at 10\% degree of significance. The study found a correlation between the level of anxiety and sleep quality $(p=0.016)$. Further research need to ascertain long-term changes in anxiety levels and sleep quality throughout medical school.
\end{abstract}

Keywords: anxiety, sleep quality, medical students 


\section{Pendahuluan}

Fakultas kedokteran merupakan salah satu program studi sarjana strata 1 yang ada dan merupakan program studi dengan tuntutan pendidikan yang tinggi. Tuntutan akademik yang dialami oleh mahasiswa kedokteran dapat menyebabkan kecemasan yang pada akhirnya berakibat pada prestasi akademik. Seorang anak yang baru lulus SMA dan memulai kehidupan sebagai Mahasiswa akan merasakan fase pergantian dalam kehidupannya karena memasuki tahap kehidupan serta lingkungan yang baru. Remaja sendiri berada dalam fase beresiko untuk mengalami gejala kecemasan. Kecemasan merupakan hal lazim yang merupakan sebuah respons dari tubuh untuk mengantisipasi masalah yang timbul. Dapat dikatakan bahwa kecemasan melekat di dalam kehidupan kita sehari hari. ${ }^{1}$ Cemas dapat dideskripsikan sebagai perasaan tertekan dan tidak tenang serta berpikiran kacau dengan disertai banyak penyesalan. ${ }^{2}$ Kecemasan dapat terjadi dalam keseharian sehari hari maupun saat sedang menghadapi sesuatu. Gejala Kecemasan sendiri dapat berupa tidak napsu makan, mual, muntah, sakit kepala, urgensi dan frekuensi urin meningkat, sesak nafas, gelisah, kehilangan motivasi. Kecemasan sendiri dibagi menjadi 4 hal yaitu kecemasan ringan, kecemasan sedang, kecemasan berat, kecemasan sangat berat/panik. ${ }^{3}$ Kecemasan yang dirasakan seseorang tidak akan menyelesaikan permasalahan yang ada di benaknya, melainkan semakin menghabiskan energy dan menyebabkan terganggunya pola tidur. ${ }^{4}$

Tidur merupakan suatu proses otak yang dibutuhkan oleh seseorang untuk dapat berfungsi dengan baik, dimana dua per tiga dari waktu manusia dihabiskan untuk tidur atau beristirahat. Seseorang dengan kualitas tidur yang rendah akan mengalami penurunan kualitas hidup, peningkatan angka sakit jantung, dan kematian lebih tinggi pada orang yang tidurnya kurang dari 6 jam atau lebih dari 9 jam per hari. ${ }^{5}$ Kebutuhan waktu tidur seseorang dalam sehari dapat berbeda-beda, dipengaruhi dari tuntutan dalam kehidupan serta pekerjaan yang dilakukan sehari hari. ${ }^{6}$

\section{Metodologi Penelitian}

Rancangan penelitian yang digunakan dalam penelitian ini adalah observasi analitik.
Penelitian ini untuk mencari hubungan tingkat kecemasan terhadap kualitas tidur pada mahasiswa UKRIDA angkatan 2018.

Penelitian ini dilakukan di Fakultas Kedokteran UKRIDA, pada bulan November 2018. Sampel pada penelitian ini adalah mahasiswa aktif Fakultas Kedokteran Universitas Kristen Krida Wacana Angkatan 2018 yang memenuhi kriteria inklusi dan telah menandatangani lembar persetujuan (informed consent) Kriteria ekslusi dari penelitian ini adalah riwayat sakit dan mengkonsumsi obatobatan dalam dua minggu terakhir atau sakit menahun. Dengan hasil penghitungan sampel sebesar 96 orang, peneliti akan mengantisipasi terjadinya kekurangan data yang akurat dan rendahnya partisipasi dengan mengambil sampel sebanyak 106 orang untuk menjadi subjek penelitian. Metode penelitian yang akan digunakan adalah simple random sampling dimana setiap orang memiliki peluang yang sama untuk dijadikan objek penelitian. Responden diminta mengisi kuesioner Zung Self Rating Anxiety Scale, dan kuesioner Pittsburg Sleep Quality Index.

\section{Kaji Etik}

Penelitian ini telah mendapatkan keterangan lolos kaji etik dari Komite Etik Penelitian Medis \& Kesehatan Fakultas Kedokteran Universitas Kristen Krida Wacana, Jakarta Barat dengan nomor pengajuan 661/SLKE-IM/UKKW/FK/ KE/XI/2018

\section{Hasil dan Pembahasan}

Penelitian ini dilakukan di Fakultas Kedokteran Universitas Kristen Krida Wacana pada bulan November 2018. Total sampel yang diperoleh pada penelitian ini yaitu 106 sampel dengan distribusi usia dan jenis kelamin yang dapat dilihat pada Tabel 1.

\section{Tabel 1. Distribusi Berdasarkan Usia dan Jenis Kelamin}

\begin{tabular}{lccc}
\hline & & \multicolumn{2}{c}{ Jenis Kelamin } \\
& & Perempuan & Laki-Laki \\
\hline Jumlah & & 73 & 33 \\
& $16-17$ & 4 & 3 \\
\multirow{2}{*}{ Usia } & 18 & 57 & 21 \\
& $19-20$ & 12 & 9 \\
\hline
\end{tabular}




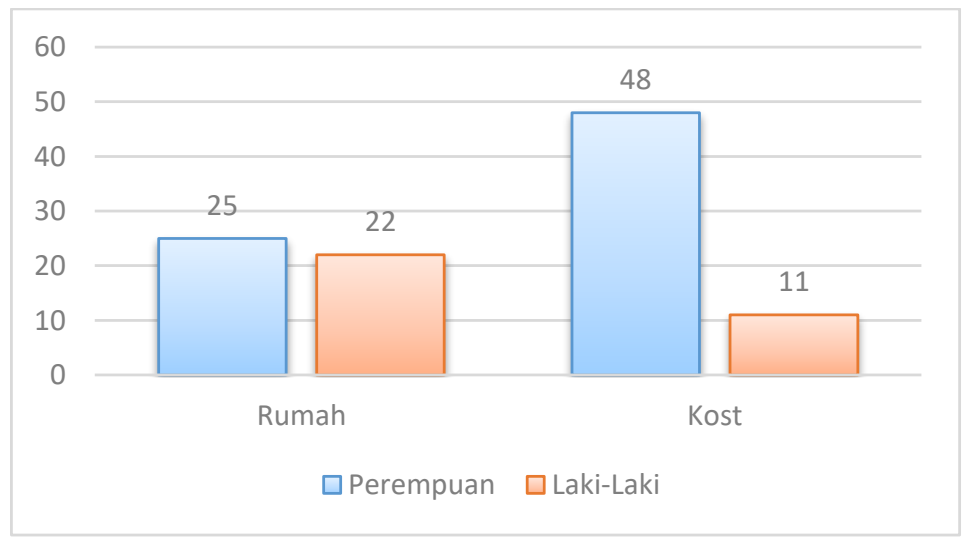

Grafik 1. Distribusi Berdasarkan Tempat Tinggal

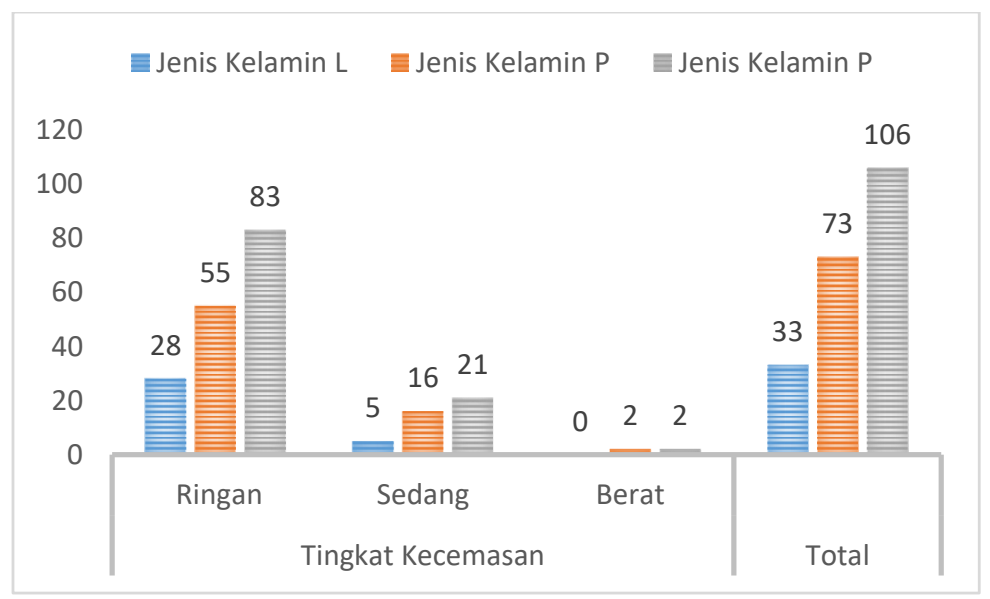

Grafik 2. Distibusi Jenis Kelamin dengan Tingkat Kecemasan

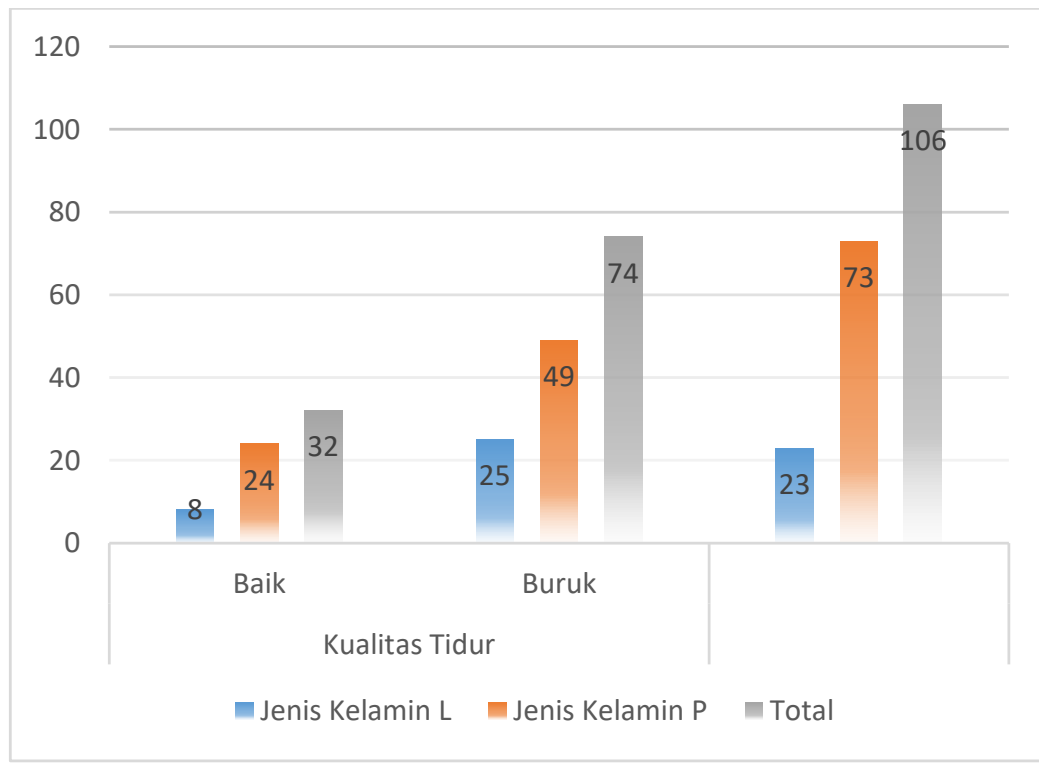

Grafik 3. Grafik Jenis Kelamin dengan Kualitas Tidur 
Tabel 2. Hubungan Tingkat Kecemasan dengan Kualitas Tidur

\begin{tabular}{|c|c|c|c|c|c|}
\hline \multirow{5}{*}{$\begin{array}{c}\text { Tingkat } \\
\text { Kecema } \\
\text { san }\end{array}$} & & \multicolumn{2}{|c|}{ Kualitas Tidur } & \multirow{2}{*}{ Total } & \multirow{2}{*}{$\begin{array}{c}\text { Pearson } \\
\text { Chi } \\
\text { Square }\end{array}$} \\
\hline & & Baik & \multirow{2}{*}{$\frac{\text { Buruk }}{53}$} & & \\
\hline & Ringan & 30 & & 83 & \\
\hline & Sedang & 1 & 20 & 21 & \\
\hline & Berat & 1 & 1 & 2 & \\
\hline Total & & 32 & 74 & 106 & 0,016 \\
\hline
\end{tabular}

Berdasarkan tempat tinggal didapatkan hasil sebanyak 47 responden (44\%) tinggal di rumah sedangkan 59 orang $(66 \%)$ tinggal di kost (Grafik 1). Berdasarkan hasil penelitian yang dilakukan didapatkan hasil penelitian dengan distribusi sebagai berikut perempuan 73 (68\%), laki-laki 33 (31\%), dengan total responden yang mengalami kecemasan berat adalah 2 responden $(0,02 \%)$, mayoritas responden melaporkan adanya kecemasan ringan $83(78 \%)$. Sebanyak 74 responden $(70 \%)$ melaporkan buruknya kualitas tidur sedangkan 32 responden (30\%) melaporkan kualitas tidur yang baik.

Berdasarkan uji Chi Square, hubungan yang bermakna secara statistik antara tingkat kecemasan terhadap kualitas tidur $(\mathrm{p}=0,016)$. Berdasarkan hasil pengamatan subjek diperoleh hasil bahwa lebih banyak subjek mengalami kecemasan ringan diperoleh dari kuesioner Zung Self Rating Anxiety Scale. Kecemasan ringan dapat dialami seseorang dalam aktifitas sehari-hari, tetapi masih dapat dikendalikan dengan baik. Gejala yang didapat antara lain seperti bernafas lebih cepat, nadi meningkat sedikit, tangan gemetar halus, sulit tertidur pulas atau sulit untuk memulai tidur. Sedangkan kecemasan sedang membuat seseorang memfokuskan dirinya kepada satu hal yang dia fokuskan saja, sehingga seseorang tersebut lebih fokus dan terarah. ${ }^{7}$

Pada penelitian sebelumnya mengenai tingkat kecemasan pada Mahasiswa Fakultas Kedokteran Universitas Udayana, dikatakan bahwa mahasiswa tingkat awal dapat mengalami tingkat kecemasan sampai $25 \%$. $^{7}$ Kecemasan adalah suatu fenomena yang komplek dan menunjukkan adanya problem psikologis lainnya. ${ }^{8,9,10}$ Respon stres yang dihasilkan akan berbeda berdasarkan status psikologis seseorang. ${ }^{11}$ Dimana semakin bertambahnya umur, semakin matang psikologi seseorang untuk beradaptasi terhadap kecemasan. ${ }^{12}$ Menurut American Psychiatric
Association (APA), gangguan kecemasan adalah kelainan psikiatrik yang paling umum. ${ }^{13,14}$ Kecemasan yang dialami seorang pasien sering dianggap oleh dokter sebagai respon normal terhadap suatu keadaan tapi dalam keadaan tertentu hal ini dapat menjadi suatu kondisi yang menyimpang yang dapat mengganggu kualitas hidup seseorang. ${ }^{15,16}$ Beberapa faktor resiko yang dapat diperhatikan adalah jenis kelamin dimana wanita lebih sering mengalami kecemasan dibanding pria. Selain itu faktor lingkungan juga turut mempengaruhi. ${ }^{17}$

Pada hasil kualitas tidur pada subjek diperoleh hasil bahwa lebih banyak subjek mengalami kualitas tidur buruk dari kuesioner Pittsburg Sleep Quality Index, hal ini menunjukan bahwa mahasiswa fakultas kedokteran Universitas Kristen Krida Wacana Angkatan 2018 memiliki waktu tidur yang kurang, sulit memasuki tidur nyenyak dan berkualitas, sulit untuk memulai tidur, dan terbangun dari tidur. Pola tidur yang terganggu akan mengubah proses metabolisme seseorang dikarenakan adanya gangguan dari proses fisiologis yang terjadi. ${ }^{18,19}$ Terapi yang diberikan adalah farmakoterapi seperti obat sedasi dan penenang, akan tetapi terapi ini ada kalanya memiliki efek samping yang lebih banyak disbanding efek terapinya. ${ }^{20}$

Berdasarkan hasil uji statistik pada penelitian ini diperoleh hasil bahwa terdapat adanya hubungan tingkat kecemasan dengan kualitas tidur pada mahasiswa Fakultas Kedokteran Universitas Kristen Krida Wacana angkatan 2018. Namun dapat disimpulkan bahwa hubungan kedua variabel ini bersifat lemah, dikarenakan beberapa faktor lain di luar kecemasan yang membuat kualitas tidur responden menjadi buruk, seperti masalah adaptasi dengan tempat tinggal, lingkungan perkuliahan, teman baru atau permasalahan keluarga serta ekonomi keluarga. Selain itu terdapat beberapa faktor lain yang dapat mempengaruhi kualitas tidur yang buruk seperti tempat tinggal yang baru tinggal di kost yang berisik, tidak nyaman dengan tempat tidur yang baru, cuaca yang berbeda.

\section{Simpulan}

Berdasarkan penelitian yang telah dilakukan, dapat diambil kesimpulan bahwa terdapat hubungan yang bermakna antara tingkat kecemasan dengan kualitas tidur pada 
mahasiswa Fakultas Kedokteran Universitas Kristen Krida Wacana Angkatan 2018.

\section{Daftar Pustaka}

1. Beesdo K, Susanne K, Dipl P, Daniel SP. Anxiety and anxiety disorders in children and adolescents: developmental issues and implications for DSM-V. Psychiatr Clin North Am. 2009;32(3):483-524.

2. Rachman S. Specific phobias and the conditioning theory of fear [Internet]. Anxiety. 2014. Hal 92-9. [diunduh 1 Juli 2019]. Tersedia dari: http://www.imd.inder.cu/adjuntos/article/ 352/Anxiety 2nd Edition.pdf

3. Zahrani A, Said M. Konseling terapi. Jakarta : Gema Insani Pers. 2015

4. Amir N. Gangguan tidur pada lansia. Cermin Dunia Kedokteran. 2008

5. Stern AS. Reflections for expectant mother. Yogyakarta: Kanisius. 2015. Hal 165.

6. Untari I. Hubungan antara kecemasan dengan prestasi uji osca I pada mahasiswa Akper PKU Muhammadiyah Surakarta. Surakarta: STIKES PKU Muhammadiyah Surakarta. 2014

7. Chandratika D, Purnawati S. Gangguan cemas pada mahasiswa semester I dan VII program studi pendidikan dokter Fakultas Kedokteran Universitas Udayana. Bali:Faal Fakultas Kedokteran Universitas Udayana. 2013

8. Rachman S. Anxiety. Third ed. Psychology Press. 2013. hal 12-20

9. Hall CS, Lindzey G. Teori psikodinamik klinis. Kanisius: Yogyakarta. 2009. Hal 80-90.

10. Sadock BJ, Sadock VA, Ruiz P. Kaplan and Sadock synopsis of clinical psychiatric. $8^{\text {th }}$ ed. New York : Lippincott Williams \& Wilkins; 2008. Hal 2063.

11. Boudarene, Berthier T. Stress, anxiety and related potensials. L'Encephale. 2017; 23:237-50

12. Ramaiah S. Kecemasan: bagaimana cara mengatasi penyebabnya. Jakarta: Pustaka Populer Obor. 2013. Hal 5-8

13. Stuart, Sundeen. Handbook of anxiety disorder. Jakarta: EGC. 2015

14. Noyes RJ, Saric RH. The anxiety disorders. Cambridge University Press. 2009. Hal 9-15

15. Aldrin N. Keajaiban kata-kata. Jakarta: Puspa Swara. 2014.
16. Shelton CI. Diagnosis and management of anxiety disorders. J Am Osteopath Assoc. 2004;104(3): S2-5.

17. Gao Y, Akers B, Roberts MB, El-Mallakh RS. Corticosterone response in sleep deprivation and sleep mentation. J Sleep Disord Manag. 2017;3(1).

18. Schlarb AA, Bihlmaier I, Hautzinger M, Gulewitsch MD, Schwerdtle B. Nightmares and associations with sleep quality and self efficacy among university students. J Sleep Disord Manage. 2015;1(1).

19. Bandelow B, Michaelis S, Wedekind D. Treatment of anxiety disorders. Dialogues Clin Neurosci. 2017;19(2):93-107.

20. Nami MT. Chronic insomnia, pharmacotherapy and the cognitive behavioral approaches. J Sleep Disorders Ther. 2014;3(1). 